\title{
Оксана Росоляк,
}

кандидат юридичних наук, доиент, доиент кафедри конституційного, адміністративного та фінансового права юридичного факультету Тернопільського національного економічного університету

\section{Ольга Дякович,} студентка групи ПРзм-21 юридичного факультету Тернопільського начіонального економічного університету

\section{ДЕЦЕНТРАЛІЗАЦІЯ ПУБЛІЧНОЇ ВЛАДИ: СВРОПЕЙСЬКИЙ ДОСВІД ТА ПОСТУП УКРАЇНИ}

Висвітлено досвід децентралізаиї у краӥнах СС та проаналізовано можливості його використання в Україні. Доведено, щз однією з передумов децентралізації публічної влади в контексті ії демократизму $і$ забезпечення народовладдя є визнання, правове врегулювання і впровадження реформи місцевого самоврядування до правової системи держави.

Ключові слова: децентралізація, адміністративна реформа, публічна влада, народовладдя, європейський досвід.

Росоляк О., Дякович $О$.

Децентрализация публичной власти: европейский опыт и продвижение Украины

Отражен опыт децеентрализации в странах ЕС и проанализированы возможности его использования 8 Украине. Доказано, что условием децентрализации публичной власти в контексте ее демократизации и обеспечения власти народа является признание, нормативное регулирование и внедрение реформы местного самоуправления в правовую систему государства.

Ключевые слова: децентрализация, административная реформа, публичная власть, народовластие, европейский опьт.

\section{Rosoliak O., Dyakovych $O$.}

Decentralization of public authority: European experience and action of Ukraine

The article describes the experience of decentralization in the EU countries and analyzes the possibilities of its use in Ukraine. It is proved that one of the prerequisites for the decentralization of public power in the context of its democratship and maintenance of executive power is the recognition, legal regulation and the influence of the reform of the municipal self-government to the legal system of the state.

Keywords: decentralization, administrative reform, public authority, democracy, European experience.

Постановка проблеми. На сучасному етапі розвитку України як правової держави важливу роль відіграє запровадження реформи органів місцевого самоврядування (децентралізації влади), яка полягає в утвердженні демократичного управління, передачі владних повноважень територіальним органам, забезпеченні та посиленні участі громадян в управлінні справами місцевого значення. Децентралізація охоплює процес перерозподілу або диспергування функцій, повноважень від центрального управління. Децентралізація як концепція набуває багатьох форм, зважаючи на історію країн, рівні розвитку, культури й підходи до державного управління, що зумовлює їі широке обговорення науковцями, експертами та громадськістю.

Аналіз основних досліджень і публікацій, в яких започатковано вирішення проблеми. Осмислення процесу децентралізації спирається на положення теорії та історії державного управління, наукові підходи таких учених, як: В. Авер'янов, Г. Атаманчук, В. Бакуменко, І. Бутко, В. Вакуленко, Т. Вютенбергер, Я. Гонціаж, І. Грицяк, В. Гройсман, Б. Гурне, Б. Данилишин, О. Ігнатенко, В. Кампо, В. Князєв, А. Коваленко, В. Копєйчиков, Д. Кохен, Л. Кравчук, В. Куйбіда, Ж. Литвак, В. Луговий, І. Надольний та ін.

Проблема децентралізації влади в Україні не є новою, проте залишається актуальною в контексті старту відповідної реформи 2014 р. та перших іiі результатів. 3 огляду на це, потребує вдосконалення та приведення у відповідність норм самої Конституції України та правове врегулювання цих проблем.

(с) Оксана Росоляк, Ольга Дякович, 2017 
Метою статті є вивчення європейського досвіду децентралізації та можливостей його використання в Україні.

Виклад основного матеріалу дослідження. Останні декілька десятиріч поняття децентралізації $є$ основним у Європі, воно також стало об'єднуючим гаслом щодо економічного розвитку регіонів у цій частині світу. Децентралізація як концепція набуває багатьох форм, зважаючи на історію країн, їхні географічні особливості, рівні розвитку, культури й підходи до державного управління. Враховуючи підписану Угоду про асоціацію між Україною та Європейським Союзом, слід особливе значення приділяти європейському розумінню та брати до уваги використані європейськими унітарними системами механізми децентралізації.

Потрібно також розрізняти децентралізацію та деконцентрацію, оскільки це дві різні концепції. Децентралізація стосується влади, компетенції та ресурсів, а деконцентрація лише компетенцій. Децентралізація - статутний, постійний, захищений правом процес передачі органам місцевої влади (муніципалітетам, радам, ОТГ тощо) завдань, повноважень та ресурсів, які досі належали центральній владі. Причиною децентралізації може бути і кількість завдань, їх різноманітність та характер, забезпечення участі громадян; і краще виконання завдань органами, які безпосередньо контактують 3 жителями населеного пункту. Основною метою такої реформи є ідентифікація та організація задоволення, насамперед колективних потреб місцевого населення (здійснення влади має починатись від найближче розташованих громадян).

Змінюючи моделі управління в Україні з акцентом на посилення місцевого самоврядування, важливо розв'язати проблеми у двох сферах: територіальній - визначення базового рівня управління, на якому може забезпечуватися ефективне управління, і фінансовій - забезпеченість рівнів управління. При цьому ключовими постають проблеми, пов'язані з оптимізацією місцевих видатків відповідно до галузевих норм навантаження на бюджетні установи та бюджетної спроможності фінансування цих установ.

Наразі в Україні реалізуються спроби об'єднання територіальних громад за затвердженою урядом методикою. Загалом це відповідає сучасним європейським тенденціям, хоча має враховувати низку застережень. Так, процеси укрупнення базового рівня адміністративно-територіального устрою відбулися в усіх європейських країнах. Зокрема, починаючи з 1950 р., загальна кількість органів місцевого самоврядування в Свропі скоротилася майже на 40 тис. Литва, Швеція і Данія зменшили кількість органів місцевого самоврядування на $80 \%$, Великобританія - на $77 \%$. Німеччина свого часу скоротила кількість общин наполовину. Реформами 1965-1977 рр. малі громади або об'єднані в більші одиниці, або ж згруповані в асоціації муніципалітетів під спільним управлінням [2].

Така тенденція була започаткована у країнах Північної Свропи, уряди яких першими прийняли рішення щодо укрупнення територіальних одиниць до розмірів, які $\epsilon$ оптимальними для реалізації урядових соціальних програм. Мотивація здійснення таких реформ, крім політичних факторів, базувалася на збалансуванні цілей економічної ефективності надання суспільних послуг і забезпечення демократії на місцевому рівні, тобто участі громади в управлінні. Теоретично зі збільшенням розміру громади збільшуються економічні вигоди завдяки ефекту від масштабу, проте знижується рівень впливу громади на прийняття рішень. Відповідно, управління віддаляється від мешканців.

Вивчення досвіду об'єднання територіальних громад і впливу розміру громади на ефективність управління нею виявило неоднозначні результати. Насамперед слід враховувати різні вихідні умови, що передували децентралізації у різних країнах. Відповідно виникають різні стратегії досягнення поставлених цілей. 3 одного боку, такі реформи націлювалися на розширення економічного потенціалу органів місцевого самоврядування для реалізації покладених на них завдань, а з іншого - передбачали збереження та укріплення місцевої демократії [5].

Так, від пріоритетності першої чи другої цілі і формувалися стратегії децентралізації. Цілі підвищення адміністративного потенціалу та ефективності територіального управління, як правило, досягалися шляхом об'єднання невеликих громад у крупні одиниці місцевого самоврядування. Пріоритет збереження невеликих муніципалітетів у європейських країнах дозволяв досягати цілей забезпечення взаємозв'язку між населенням і владою, а оперативні завдання місцевого значення розв'язуються шляхом формування проміжних структур міжмуніципального співробітництва.

Польський дослідник Павел Антковяк зазначає, що найважливішими особливостями самоврядування є такі:

- правові положення повинні захищати право місцевого населення (територіальної громади чи органу місцевого самоврядування) керувати «власними» справи;

- місцева громада бере участь у обов'язковому здійсненні самоврядування на підставі закону (членом органу місцевого самоврядування можна стати відвовідно до вимог закону, а не лише з власної волі); 
- територіальна громада та органи місцевого самоврядування виконують публічні завдання, що належать до їх компетенції;

- це управління відбувається за принципами незалежності (децентралізації) органів влади;

- введення форми нагляду в діяльність органів самоврядування можливе лише і виключно у формах, передбачених законом, таким чином, що не порушує незалежності в прийнятті рішень органами місцевого самоврядування [10].

Загалом серед країн Європи виділяють дві узагальнені схеми об'єднання територіальних громад: північноєвропейська, в рамках якої відбувалося формування крупних муніципалітетів (Швеція, Англія) та південноєвропейська - з об’єднанням громад у невеликі муніципалітети (Франція, Італія). Відповідно сформувалися і різні за розміром та повноваженнями муніципалітети. У Швеції середній розмір громади становить 34 тис. мешканців, у Данії - 55 тис., в Англії - 120 тис. У деяких землях Німеччини реформи привели до збільшення середнього розміру муніципалітету до 45 тис. жителів [7].

Таке масштабне укрупнення муніципалітетів суттєво підвищило фінансово-економічні складові управлінського потенціалу органів місцевого самоврядування і зробило їх багатофункціональними. У більшості країн Європи територіальні реформи з суттєвого укрупнення муніципалітетів офіційно були добровільними, як це анонсується і в Україні. Проте в реальності ступінь добровільності був не надто високим, і територіальні реформи проводилися із суттєвою примусовою складовою. Як правило, на рівні уряду створювалися комісії, які готували рекомендації щодо створення нового територіального формату системи місцевого самоврядування.

Добровільна фаза у процесі об’єднання громад переважно стосувалася деталей адаптації громад до запропонованого урядом плану територіальної структури. Якщо ж добровільно консенсусу не вдавалося досягнути, то рішення про об'єднання приймалося централізовано. Такий досвід добровільного об'єднання громад необхідно враховувати і при здійсненні подібних заходів в Україні. Очевидно, що у даній сфері виникатиме чимало суб'єктивних конфліктів, які не дозволять прийняти оптимальне рішення 3 позицій підвищення ефективності управління.

Інша модель формування дієвого місцевого самоврядування - в Іспанії, Швейцарії, Італії та Франції, у яких кількість муніципалітетів не змінилася. Остання взагалі є лідером у Європі за кількістю органів місцевого самоврядування - їх там понад 36 тис, а кількість населення у більшості з них не перевищує 2 тис. Проте більшість функцій там реалізується через інститути міжмуніципального співробітництва, яких у Франції створено понад 2,5 тис. Такі інститути можуть мати різну організаційну форму і виконувати різні функції. Їх створення і функціонування є добровільним і виходить $з$ ініціативи громад, завдання яких вони покликані виконувати. Такий підхід суттєво відрізняється від централізовано спланованого об'єднання громад і забезпечує індивідуальні рішення різних територіальних проблем [1].

Загалом основною тенденцією процесів адміністративно-територіального реформування $\epsilon$ утворення міцних базових адміністративно-територіальних одиниць, спроможних здійснювати місцеве самоврядування. Проте питання розмірів та функцій, які вони повинні виконувати, є індивідуальним не тільки для країни, а й навіть у межах окремих регіонів, тому воно повинно вирішуватися за безпосередньої участі територіальних громад.

Логічно припустити, що в країнах 3 невеликими муніципалітетами більшість повноважень закріплено за центральним рівнем. Цьому є докази. Наприклад, освіта у Франції є високоцентралізованою. Центральний уряд керує кадровою політикою на всіх рівнях і складає загальні плани розміщення закладів освіти. Роль муніципалітету обмежена формуванням та утриманням шкільного майна i покриттям поточних витрат, не пов'язаних з навчанням. Литва з відносно великими муніципалітетами дотримується протилежного курсу. Місцева влада тут оплачує зарплату і має формальну функцію контролю за наймом та просуванням по службі персоналу, а також відповідає за формування та утримання шкільного майна [2].

Реформа органів місцевого самоврядування в Україні передбачає об'єднання (укрупнення) територіальних громад. Це здійснюється через те, що надмірна частина ресурсів у невеликих громадах і далі витрачатиметься на утримання управлінського апарату, а для реалізації серйозних проектів місцевого розвитку коштів не вистачатиме. І навіть наділення додатковими фінансовими ресурсами переважної більшості наявних дрібних територіальних громад, їхньої спроможності не забезпечить. Тому реформа місцевого самоврядування, враховуючи позитивний як європейський, так і власний історичний досвід, передбачає обов’язкове об’єднання (укрупнення) територіальних громад [9].

Варто також зазначити, що укрупнення території громад не може бути довільним, воно має свої логічні межі. Відстань від центру громади до іiі найдальшого населеного пункту має бути такою, щоб у 
екстрених випадках її не довше, ніж за 30 хвилин могли подолати пожежна команда, швидка допомога, поліцейський патруль тощо. Допомога, надана через більший проміжок часу, різко втрачає ефективність [9].

Очевидно, що добровільно об’єднати усі громади в Україні не вдасться, тому залишаючи можливість для існування малих громад, важливо забезпечити їх інструментарієм розв’язання спільних iз сусідніми громадами проблем. Серед українських 12 тис. територіальних громад половина є малими 3 населенням менше 3 тис осіб. Тож основні реформаційні зусилля потрібно спрямувати саме на них, бо в існуючих умовах вони не мають шансів на ефективне самоуправління [5].

Досвід зарубіжних країн та найновіші наукові дослідження дозволяють виокремити такі передумови успішної імплементації децентралізаційних явищ та ефективного управління в системі децентралізованої влади:

- утвердження принципу верховенства права;

- визнання та гарантії місцевого самоврядування;

- демократичне й ефективне виборче законодавство;

- незалежність, ефективність, доступність і прозорість судової системи;

- досконалий бюджетний процес та висока фінансова дисципліна;

- наявність адекватних соціальних стандартів;

• розвинутий громадський сектор або стійка тенденція до його розвитку.

Україна вже зробила перші кроки на шляху до успішного впровадження реформ децентралізації влади. Йдеться про:

- Закони про внесення змін до Бюджетного та Податкового кодексів України. Завдяки цим змінам за три роки місцеві бюджети зросли на 78 млрд. грн.: 3 68,6 млрд. в 2014 до 146,6 млрд. грн. в 2016 р. Частка місцевих бюджетів у зведеному бюджеті України постійно зростає і на кінець 2017 р. наближається до 50\% (у 2015 p. $-45,6 \%$ ).

- закон України «Про добровільне об’єднання територіальних громад». Цей Закон започаткував спроможний базовий рівень місцевого самоврядування. На початок 2017 р. створено вже 366 об'єднаних територіальних громад (ОТГ), які уряд визнав спроможними. До складу цих ОТГ увійшли близько 1800 колишніх місцевих рад. 30 квітня та 29 жовтня 2017 р. перші вибори пройшли ще у 248 ОТГ. 24 грудня 2017 р. обиратимуть своїх місцевих лідерів ще у 51 об’єднаній громаді. Зараз 5,7 млн. людей проживають в ОТГ. Такі темпи міжмуніципальної консолідації міжнародні експерти називають дуже високими. Закон також запровадив інститут старост в ОТГ, які представляють інтереси сільських мешканців в раді громади. Сьогодні обрано вже більше 600 старост, ще більше 1,7 тисяч осіб виконують обов’язки старост.

- Закон «Про співробітництво територіальних громад», який створив механізм вирішення спільних проблем громад: утилізація та переробка сміття, розвиток спільної інфраструктури тощо.

- Закон «Про засади державної регіональної політики». Державна підтримка регіонального розвитку та розвитку інфраструктури громад за час реформи зросла у 30 разів: 3, 0,5 млрд. в 2014 р. до 14,9 млрд. грн. у 2017 р. 21 область прийняла рішення про створення Агенції регіонального розвитку, в усіх областях працюють Центри розвитку місцевого самоврядування, які в тому числі допомагають місцевій владі втілювати регіональні стратегії.

- Закон «Про внесення змін до деяких законодавчих актів України щодо децентралізації повноважень у сфері архітектурно-будівельного контролю та удосконалення містобудівного законодавства». Нові містобудівні повноваження отримали вже майже 90 міст та ОТГ.

- Пакет законів щодо розширення повноважень органів місцевого самоврядування та оптимізації надання адміністративних послуг. Це дозволило делегувати органам місцевого самоврядування відповідного рівня повноваження з надання базових адміністративних послуг: реєстрацію місця проживання, видачу паспортних документів, державну реєстрація юридичних та фізичних осіб, підприємців, об'єднань громадян, реєстрацію актів цивільного стану, речових прав, вирішення земельних питань тощо [8].

Певні успішні кроки на шляху реформування публічної влади свідчать, що Україна обрала правильний напрямок і треба рухатися ним далі. Але без внесення відповідних змін до Конституції України щодо децентралізації завершити реформу та досягти європейського розвитку нашої країни буде неможливо. Зокрема, потрібно на конституційному рівні закріпити статус об'єднаної територіальної громади (ОТГ), привести у відповідність систему органів державної виконавчої влади та органів місцевого самоврядування, узгодити їхні функції та повноваження, дотримуючись принципу субсидіарності та уникнувши дублювання. 
Росоляк О., Дякович О.

Децентралізація публічної влади: європейський досвід та поступ України

Отже, однією з передумов децентралізації публічної влади в державі як запоруки їі демократизму і забезпечення народовладдя є визнання, нормативне врегулювання і впровадження реформи місцевого самоврядування до правової системи держави. Саме тому вивчення досвіду європейських країн щодо реформування адміністративно-територіального устрою і організації та функціонування публічної адміністрації має велике значення для запровадження ефективної системи місцевого самоврядування в Україні і це посилить економічну зацікавленість територіальних громад у створенні та розвитку нових виробництв, підтримці бізнесу, розвитку регіонів та України загалом.

\section{Список використаної літератури}

1. Бабінова О. О. Державна регіональна політика і регіональний розвиток : сучасні реалї Украӥни та європейський досвід / О. О. Бабінова. - К. : Фенікс, 2011. - 268 с.

2. Борденюк В. I. Місцеве самоврядування та державне управління: конституційно-правові основи співвідношення та взаємодії : моногр. / В. І. Борденюк. - К. : Парлам вид-во, 2007. - 576 с.

3. Бориславська О. Децентралізачія публічної влади : досвід європейських країн та перспективи Украӥни / О. Бориславська, I. Заверуха, Е. Захарченко [та ін.]; [Електронний ресурс]. Швейцарсько-украӥнський проект «Підтримка децеентралізаиії в Україні - DESPRO. - K. : TOB «Софія». - 2012. - 128 с. - Режим дocmyny : http://despro.org.ua/media/upload/decentral_zac_ya_publ_chno_vladi_dosv_d_evropeyskih_derzhav_ ta_perspektivi_ukra_ni(2).pd.

4. Брюке Ф. Форми регіоналізащиї в Свропі / Ф. Брюке // Організація регіональної та місиевої влади: досвід держав-членів Свропейського Союзу : Спеціальне доповнене видання Українсько-європейського журналу з міжнародного та порівняльного права. - К. : Вид-во ТОВ «Украӥнська консалтингова груna», 2005. $-128 \mathrm{c}$.

5. Їжак О. Принциип субсидіарності СС і межі його застосування в Украйні / О. Їжак [Електронний реcypc]. - Режим достуny : http://db.niss.gov.ua/ docs/polmil/185.htm.

6. Теорія та практика європейського врядування : навч. посіб. / Л. Л. Прокопенко, О. М. Рудік, I. А. Шумляєва, Н. М. Рудік. - Д. : ДРІДУ НАДУ, 2009. - 216 с.

7. Ткачук А. Місиеве самоврядування та децентралізація : практ. посіб. / А. Ткачук ; Швейцарсько-український проект «Підтримка деиентралізаиії в Україні-DESPRO». - К. : ТОВ «Софія», 2012. - 186 с.

8. Державна політика, законодавчі напрацювання, проміжні результати першого етапу децентралізації влади в Украӥні [Електронний ресурс]. - Режим достуnу : http://decentralization.gov.ua/about.

9. Суть реформи органів місиевого самоврядування (децентралізації) [Електронний ресурс]. - Режим docmyny : http://icps.com.ua/assets/uploads/images/files/verstka_decentralizaciya.pdf.

10. Pawet Antkowiak. Decentralizacja władzy publicznej w Polsce na przykadzie samorzadu terytorialnego [Електронний ресурс]. - Режим доступy : https://repozytorium.amu.edu.pl/bitstream/10593/4046/1/ Pawe\%C5\%82\%20Antkowiak\%20-\%20Decentralizacja\%20w\%C5\%82adzy\%20publicznej\%20w\%20 Polsce.pdf.

\section{References}

1. Babinova, O. O. (2011). Derzhavna rehional'na polityka i rehional'nyy rozvytok : suchasni realiyi Ukrayiny ta yevropeys'kyy dosvid [State regional policy and regional development: modern realities of Ukraine and European experience]. Kyiv : Feniks [in Ukrainian].

2. Bordenyuk, V. I. (2007) Mistseve samovryaduvannya ta derzhavne upravlinnya: konstytutsiyno-pravovi osnovy spivvidnoshennya ta vzayemodiyi : monohrafiya [Local Self-Governance and Public Administration: Constitutional and Legal Foundations of Relationship and Interaction]. Kyiv : Parlam. publishing [in Ukrainian].

3. Boryslavs'ka, O., Zaverukha I., Zakharchenko E. ]; (2012) Detsentralizatsiya publichnoyi vlady : dosvid yevropeys'kykh krayin ta perspektyvy Ukrayiny [Decentralization of public authority: experience of European countries and prospects of Ukraine] Swiss-Ukrainian project "Support for Decentralization in Ukraine DESPRO. - Kyiv.: LLC «Sofia»Retrieved from http://despro.org.ua/media/upload/decentral_zac_ya_publ_ chno_vladi_dosv_d_evropeyskih_derzhav_ta_perspektivi_ukra_ni(2).pd [in Ukrainian].

4. Bryuke, F. (2005) Formy rehionalizatsiyi v Yevropi [Forms of regionalization in Europe]. Kyiv : "Ukrayins'ka konsaltynhova hrupa» [in Ukrainian].

5. Yizhak, O. Pryntsyp subsydiarnosti ES i mezhi yoho zastosuvannya v Ukrayini [The principle of subsidiarity of the EU and the limits of its application in Ukraine]. Retrieved from http://db.niss.gov.ua/docs/polmil/185. htm [in Ukrainian]. 
6. Prokopenko, L. L., O. M. Rudik, I. A. Shumlyayeva, N. M. Rudik (2009) Teoriya ta praktyka yevropeys'koho vryaduvannya : navch. Posib [Theory and Practice of European Governance] Dnipro. : DRIDU NADU [in Ukrainian].

7. Tkachuk A. (2012) Mistseve samovryaduvannya ta detsentralizatsiya : prakt. posib. [Local government and decentralization] Kyiv : «Sofiya» [in Ukrainian].

8. Derzhavna polityka, zakonodavchi napratsyuvannya, promizhni rezul'taty pershoho etapu detsentralizatsiyi vlady v Ukrayini (2017) [State policy, legislative developments, interim results of the first stage of decentralization of power in Ukraine]. Retrieved from http://decentralization.gov.ua/about [in Ukrainian].

9. Sut' reformy orhaniv mistsevoho samovryaduvannya (detsentralizatsiyi) [The essence of the reform of local self-government (decentralization)]. Retrieved from http://icps.com.ua/assets/uploads/images/files/verstka decentralizaciya.pdf [in Ukrainian].

10. Paweł Antkowiak. (2011) Decentralizacja władzy publicznej w Polsce na przykadzie samorzadu terytorialnego [Decentralization of public authorities in Poland on the example of local government]. Retrieved from https://repozytorium.amu.edu.pl/bitstream/10593/4046/1/Pawe\%C5\%82\%20Antkowiak\%20-\%20 Decentralizacja\%20w\%C5\%82adzy\%20publicznej\%20w\%20Polsce.pdf [in Polish].

Стаття надійшла до редакції 23.11.2017. 